\title{
Gaziantep Yöresi Halk Oyunları Çalışmalarının Üniversite Öğrencilerinin Vücut Kompozisyonu ve Fiziksel Uygunlukları Üzerine Etkisi
}

\author{
The Effects of Gaziantep Region Folk Dances Training on The Body Composition \\ and Physical Fitmess of University Students
}

\author{
ORİJINAL ARAŞTIRMA/ \\ ORIGINAL RESEARCH \\ Burak KORKMAZ ${ }^{*}$, \\ Oğuzhan YONCALIK ${ }^{2}$, \\ Aziz GÜÇLÜÖVER ${ }^{3}$
}

${ }^{1}$ Kırıkkale Üniversitesi, Sağlık Bilimleri Enstitüsü, Kırıkkale. http://orcid.org/ 0000-0002-6641-9221

${ }^{2}$ Osmaniye Korkut Ata Üniversitesi, Osmaniye. https://orcid.org/0000-0003-2289-1257

${ }^{3}$ Kırıkkale Üniversitesi, Spor Bilimleri Fakültesi, Kırıkkale.

https://orcid.org/0000-0003-1014-5011

\section{Yayın Bilgisi}

Gönderi Tarihi: 12.10 .2018

Kabul Tarihi: 25.12.2018

Online Yayın Tarihi: 31.12.2018

\begin{abstract}
$\ddot{\mathbf{O z}}$
Bu araştırma Kırıkkale Üniversitesi öğrencilerinin Gaziantep Yöresi Halk Oyunları çalışmaları sonrası vücut kompozisyonları ve fiziksel uygunluklarındaki değişimi belirlemek amacıyla yapılmıștır. Araștırma, 2015-2016 eğitim öğretim yılı bahar döneminde Kırıkale Üniversitesi'nde öğrenim gören 60 öğrenci ile gerçekleştirilmiştir. Denekler 2 gruba ayrılmıştır ve gönüllülük esasına göre bir gruba temel halk oyunları öğretim yöntem ve teknikleri kullanılarak 12 hafta boyunca halk oyunları antrenman programı yürütülmüştür. Deneklere halk oyunları çalışmalarından önce ve sonra olmak üzere iki ölçüm uygulanmıştır. Bu ölçümlerde deneklerin; boy uzunluğu, vücut ağırlığı, vücut yağ oranları, kuvvet ölçümleri, sürat ölçümleri, çeviklik ölçümleri, esneklik ölçümleri ve bazı vücut çevre uzunluk değerleri ölçülmüştür. $\mathrm{Bu}$ çalışmada tanımlayıcı istatistiklerinin analizinde SPSS 16.0 for Windows paket programı kullanılmıştır. Elde edilen değerler arasındaki anlamlılık düzeyi $\mathrm{p}<0.05$ olarak belirlenmiştir. Araştırmaya katılan deney grubu $(n=30)$ öğrencilerinin yaş ortalamas $20.43 \pm 1.1$ yıl, kontrol grubu $(n=30)$ öğrencilerinin yaş ortalaması $20.87 \pm 1.0$ yıl olarak bulunmuştur. Deney grubu öğrencilerinin boy ortalamas1 $171.67 \pm 9.5 \mathrm{~cm}$, kontrol grubu öğrencilerinin boy ortalamas1 $172.07 \pm 8.6$ $\mathrm{cm}$, deney grubu öğrencilerinin ortalama ağırlığ $63.973 \pm 10.5 \mathrm{~kg}$ olarak saptanmıştır. Sonuç olarak 12 hafta süreyle 36 oturumda, her bir çalışmada 90 dakika süreyle yapılan Gaziantep Yöresi halk oyunlarını oynayan öğrencilerin, vücut yağ oranında ve vücut ağırlığı değerlerinde düşüş, esneklik, çeviklik, sürat ve kuvvet parametrelerinde artış ortaya çıktı̆̆ tespit edilmiştir. Bu değişiklikler 0.01 ve 0.05 anlamlılık düzeyinde istatistiksel olarak ifade edilmiştir. Beslenme ve diyet programları uygulanarak halk oyunları çalışmaları yapılıp, beslenmenin etkileri incelenebilir. Vücut yağ oranı önemli olan branşlarda, bu çalışma yardımcı antrenman olarak uygulanabilir. Anahtar Kelimeler: Halk Oyunları, Vücut Kompozisyonu, Fiziksel Uygunluk, Spor
\end{abstract}

\begin{abstract}
The main objective of this research is to determine the link between Turkish Folk Dance and changes it causes to the human body composition. The research has been conducted by analysing the changes 60 participants (who were studying in 2015-2016 in Kırıkkale University students), experienced as a result taking part in folk dance activities originating from Gaziantep Region. For the purpose of the experiment the participants were split in to two groups. The first group was referred to as "Experimental Group" and second group referred to as "Control Group". The experiment commenced by providing a twelve week training session to the experimental group and comparing the changes in their body Composition to those in the control group who weren't given the training. Measurements of the participants were taken before and after their lessons. The measurements taken included height, body weight, body fat, strength, stamina, and flexibility. The statistical analysis was obtained using SPSS 16.0 windows programme. To test the significance of the results the $p$ value used is 0.05 . Participants in the experimental group $(n=30)$ had an average age of $20.43 \pm 1.1$, control group $(n=30)$ had an average age of $20.87 \pm 1.0$. The participants in the experimental group had an average height of $171.67 \pm 9.5 \mathrm{~cm}$, in comparison to the control group $17.07 \pm 8.6 \mathrm{~cm}$. In relation to the participants weight the experimental group had an average of $63.973 \pm 10.5 \mathrm{~kg}$. Gaziantep Folk Dance students completed thirty six sessions with a duration of ninety minutes each session over a twelve week period. The results showed a decrease in body fat and weight. However an increase in flexibility, stamina and strength. These results were all statistically significant, as the $\mathrm{p}$ value was below the threshold of 0.05 . Nutritional and diet programs can be applied by applying folk dances. So the effects of nutrition can be exammed. In branches which the body fat ratio is important this study can be applied as a training.

Keywords: Folk Dancing, Body Composition, Physical Fitness, Sport
\end{abstract}

\footnotetext{
*Sorumlu yazar: Burak Korkmaz, korkmazzburakk@gmail.com
} 


\section{GİRIŞ}

Halk oyunları, tarihsel gelişimi itibariyle, bireyin doğasında bulunan duygu ve düşünceleri, hareket aktiviteleriyle ortaya koyma ve aynı zamanda toplumsal bir varlık olması nedeni ve birlikte olma şuurunu sergilemesiyle önemli bir araç olarak kullanılmaktadır. İnsan fizyolojisinde çeşitli yönleriyle görülebilecek, uzun süreli uyumdan kaynaklanabilecek değişimi ve etkileşimi çeşitli boyutlarıyla ortaya koymak yapılacak olan bilimsel araştırmalara bağlıdır (Ünveren, 2006).

Halk oyunları kendi içinde kompleks hareketler içeren, çok yönlü hem sportif ve hem bilişsel beceriler gerektiren bir takım oyunudur. Halk oyunlarında dansçıların sahip olması gereken öğelere baktığımızda; dayanıklılık, patlayıcı kuvvet, kuvvette devamlılık gibi biyomotor özellikler ön plana çıkmaktadır. Halk oyunları günümüzde sanatsal ve kültürel özelliğinin yanında sportif bir kimliğe bürünerek varlığını sürdürmektedir. Çıkış kaynağındaki çoğu özelliğini kaybetmesine rağmen, eğlenmek için bir araya gelmiş insanların vazgeçilmez davranışlarından biri haline gelmiştir (Önal, 2017).

Ceyran'a (2001) göre, Halk oyunları ülkemizde uzun bir geçmişe sahip olmasına rağmen önemsenmemiş ve gelişmemiş bir spor, bir kültürel aktivite olmasından dolayı bu alanda yapılan çalışmalar diğer sportif dallara göre az sayıdadır. Halk oyunları çalışmaları, gösterileri, yarışmaları süresi kısa da olsa üst düzey performans gerektirdiği için dansçıların antropometrik özellikleri ve fiziksel uygunlukları büyük önem taşımaktadır.

Tanım olarak fiziksel uygunluk, fiziksel aktivite tarafindan etkilenen vücut sisteminin fizyolojik kapasitesidir. Fiziksel uygunluk iki şekilde değerlendirilmektedir; sağlıkla ilgili fiziksel uygunluk ve performansla ilgili fiziksel uygunluk (Özer, 2001).

Vücut kompozisyonu genel olarak yağ, kemik, kas hücreleri, diğer organik maddeler ve hücre dışı sıvılardan oluşmuştur. İnsan yaşantısını yakından ilgilendiren vücut kompozisyonunu etkileyen faktörler; yaş, cinsiyet, kas, fiziksel aktivite düzeyleri, hastalıklar ve beslenmedir. Vücut kompozisyonunu yağlı ve yağsız kütleler olarak ikiye ayırabiliriz. Yağsız kütlelere; kas, kemik, su, sinir, damarlar ve diğer organik maddeler girmektedir. Yağlı kütleler ise; derialtı yağları, depo yağları ve esansiyel (öz) yağlar olarak sınıflandırılmaktadır (Zorba, 2001). 
Korkmaz, B., Yoncalık, O. ve Güçlüöver, A. (2018). Gaziantep yöresi halk oyunları çalı̧̧malarının üniversite öğrencilerinin vücut kompozisyonu ve fiziksel uygunlukları üzerine etkisi. CBÜ Beden Ĕgitimi ve Spor Bilimleri Dergisi, 13(2), 388-404.

Sporda başarılı olunması öncelikle fiziksel özelliklere bağlı olup antropometrik özellikler, cinsiyet ve kişilere göre farklılık gösterebilmektedir. Halk oyunlarında kolların, bacakların ve ayakların koordineli bir şekilde kullanılmasının yanı sıra bireylerin fiziksel, fizyolojik ve motorik özelliklerini de etkilediği düşünülmektedir. Tüm bu tanımlamalardan hareketle yapılan bu çalışma, halk oyunları çalışmalarının üniversite öğrencilerinin vücut kompozisyonları ve fiziksel uygunlukları üzerine etkisinin olup olmaması araştırılıp, ortaya açısından konulması önem arz etmektedir.

Halk oyunları çalışmaları sonrası hem vücudunu hem de beynini daha koordineli kullanabilecek bireylerin, çeviklik, esneklik, denge, vücut yağ oranları ve kilo gibi özelliklerin dengelenmesi ve düzenlenebilmesi araştırmanın önemlerindendir. Halk oyunları çalışmaları sonucunda bireylerde meydana gelebilecek olumlu yöndeki reaksiyon zamanı, daha sonraları bireylerin başka becerilerin ve dikkat faktörünün gelişmesi bakımından önem arz etmektedir. Sonuç olarak bu araştırmanın hipotezi 12 haftalık halk oyunları çalışmalarının, katılımcıların fiziksel uygunluk parametreleri üzerinde olumlu değişimler göstermesi amaçlanmıştır.

\section{YÖNTEM}

\section{Çalışma Grubu}

$\mathrm{Bu}$ çalışmada deney ve kontrol gruplarından birine müdahale ile yapılan yarı deneysel araştırma modeli uygulanmıştır. Araştırmanın örneklemini Kırıkkale Üniversitesi’nde öğrenim gören ve daha önce halk oyunları oynamamış olan 30 erkek, 30 kız toplam 60 öğrenci gönüllü olarak katılmıştır. Katılımcıların tamamı Kırıkkale Üniversitesi’nin öğrencilerinden oluşmaktadır ve Halk Oyunları Topluluğuna katılmak isteyen Eğitim Fakültesi, Mühendislik Fakültesi Fen Edebiyat Fakültesi ve Sağlık Bilimleri Fakültesi öğrencilerinden seçilmiştir. Katılımcı bireyler 20-25 yaş arası kız, erkek, sedanter ve sağlık problemi olmayan öğrencilerdir. Toplam 30 kız 30 erkek öğrenciden, halk oyunları oynamak isteyen 15 kız, 15 erkek deney gurubu, diğer 15 kız, 15 erkek ögrenci ise kontrol grubunu oluşturdu. Çalışmanın uygulanabilmesi için gerekli tüm izinler alınmıştır. Araştırmaya katılan tüm öğrencilere, çalışma hakkında bilgi verilmiş ve gönüllü onay formu imzalatılmıştır. 
Korkmaz, B., Yoncalık, O. ve Güçlüöver, A. (2018). Gaziantep yöresi halk oyunları çalı̧̧malarının üniversite öğrencilerinin vücut kompozisyonu ve fiziksel uygunlukları üzerine etkisi. CBÜ Beden Ĕgitimi ve Spor Bilimleri Dergisi, 13(2), 388-404.

\section{Veri Toplama Aracı}

$\mathrm{Bu}$ araştırmada ön test ve son test olmak üzere iki kere veri toplanmıştır. Hem ön testte hem de son testte deneklerin, boy uzunluğu, vücut ağırlığı, vücut kompozisyonu ve antropometrik ölçümler birer kez, el kavrama kuvveti, sürat koşusu, zig zag koşusu, esneklik ve dikey sıçrama testleri, performansa dayalı olduğu için üçer kez alınmıştır. Bu uygulanan testlerde 3 tekrardan en iyi sonuç alınıp verilere kaydedilmiştir. Tüm testlerden önce ölçüm yapılacak cihazların ve malzemelerin kalibrasyonu ve doğrusallık kontrolü yapılıp güvenilirliği test edilmiştir. Antropometrik ölçümler, vücut kompozisyonu, esneklik, el kavrama kuvveti ve dikey sıçrama ön testleri 03-04 Mart 2015, son testleri ise 30-31 Mayıs tarihlerinde Kırıkkale Üniversitesi Eğitim Fakültesi Egzersiz ve Performans Laboratuvarı'nda, sürat koşusu ve zig zag çeviklik koşusu ölçümleri de, Kırıkkale Üniversitesi Eğitim Fakültesi Kapalı Spor Salonu'nda yapılmıştır.

\section{Verilerin Analizi}

İstatistiksel sonuçların çıkarılmasında SPSS İstatistik programı kullanılmıştır. Deney ve Kontrol gruplarının kendi içinde analizinde Bağımlı Örneklem t-Testi kullanılmıştır. Kovaryans analizi yapılması için Shapiro-Wilk normallik testi uygulanmış, 0.01 ile 0.05 anlam düzeyinde karşılaştırmalar yapılmış̧ır.

\section{Halk Oyunları Antrenman Süreci}

Bu çalışmada kontrol grubu 12 haftalık süreçte, haftada 3 gün olacak şekilde 36 antrenman oturumuna katılmışlardır. Bu 12 haftalık dönemde katılımcılara Gaziantep Yöresi'nin 11 oyunu öğretilmiştir. Bu oyunlar belirlenirken oyunların, temposuna, ritmine ve vücudun ne kadar fazla bölgesine etkisi olabileceğine bakılmıştır. Çalışmanın ilk haftasında temel halk oyunları figürleri gösterilip, oyuncuların halk oyunlarına adapte sürecini hızlandırmak hedeflenmiştir. Katılımcıların halk oyunları çalışmalarının günleri dışında herhangi bir başka antrenman veya yüksek tempolu bir aktivite yapmamaları istenmiştir. Her antrenmandan önce ısınma hareketleri yapılmıştır. Antrenmanlarda yoğunluğu ve şiddeti artırmak için öğrenilen oyunlar davul eşliğinde ritimle tekrar edilmiştir. Ritimle yapılan antrenman öğrenilen oyunları hem kalıcı hale getirmek hem de ritme göre tam öğrenmeyi sağlamak hedeflenmiştir. Halk oyunları antrenmanları her bir oturumda 45 'er dakikadan iki bölüm olarak yapılmıştır. Bölümler 
Korkmaz, B., Yoncalık, O. ve Güçlüöver, A. (2018). Gaziantep yöresi halk oyunları çalı̧̧malarının üniversite öğrencilerinin vücut kompozisyonu ve fiziksel uygunlukları üzerine etkisi. CBÜ Beden Ĕgitimi ve Spor Bilimleri Dergisi, 13(2), 388-404.

arasında 15 dakikalık dinlenme süresi vardır. Halk oyunlarının temel figürleri (çift sol, çift sağ, yedili sekme vb.) ilk hafta öğretilmiştir. Gaziantep yöresinden seçilen 11 oyun (yarım kaba, düz, şirvani, galata, pekmez, zennube, teze gelin, şekeroğlan, demirci, havarişko, oğuzlu) öğretilirken, tüm oyunların figürleri ve hareketleri en küçük parçalarına indirilerek anlatılmış ve uygulanmıştır. Öğretim aşamasında tam öğrenme modeli benimsenmiş olup, oyun öğretimi parçadan bütüne doğru gitmiştir. Bir figür öğrenilmeden yeni bir figüre geçilmemiştir. Eksiklerle ilgili ek öğrenme yapılıp, öğrenme tamamlanmıştır. Antrenmanlarda kontrol grubuna oyunlar öğretilirken, anlatım ve gösterip yaptırma yöntem ve teknikleri kullanılmıştır. Yapılan halk oyunları antrenmanları sürecinde Bompa'nın (2014) antrenman öğeleri dikkate alınmış olup, çalışmalar buna göre planlanmıştır. Halk oyunları antrenmanlarının süresi veya zamanı 45'er dakikalık iki bölümden haftada 3 gün olacak şekilde 12 hafta sürmüştür. Halk oyunları antrenman sıklı̆g 1 ise 1 gündür, çalışmalar bir gün yapılıp bir sonraki gün dinlenme olacak şekilde planlanmıştır.

\section{Araştırmada Test Edilen Değişkenler ve Ölçüm Yöntemleri}

Tüm katılımcıların boy uzunluğu, vücut ağırlığı, yağ yüzdeleri ve antropometrik değerleri ölçülerek belirlenmiş, el kavrama kuvveti, sürat koşusu, zig zag çeviklik koşusu, esneklik ve dikey sıçramada ise performans testleri uygulanıp veriler kayda alınmıştır.

Boy Uzunluğu: Katılımcıların boy uzunlukları, çıplak ayakla ve ayakları bitişik olacak şekilde, ölçüm duvarı önünde, vücudun ve başın dik olması koşuluyla ölçülmüsstür. Değerler 'cm' cinsinden kaydedilmiştir.

Vücut Ăğırlığı: Katılımcıların vücut ağırlık ölçümleri $50 \mathrm{~g}$ hassasiyetinde olan EKO-150 kg 40x50 Tartım Baskülü kullanılmıştır. Katılımcıların üzerinde sadece şort ve atlet varken ölçüm alınmıştır.

Vücut Yağ Oranı: Bu çalışmada katılımcıların vücut yağ yüzdelerinin ölçümü için 'Tanita Body Composition Analyzer BC 418' markalı analizör kullanılmıştır. Ölçümlerden önce cihazın kontrolü ve kalibrasyonu yapılmıştır. Her deneğin ölçümü yapılırken önce üzerine basılan, çelik ayak koyma yerleri ve el ile tutulup sıkılan tutma kolu sslak bez ile temizlenip kurulanmıştır. Ölçüm sırasında analizör ekranına elektronik olarak her deneğin cinsiyeti, yaşı, boy uzunluğu ve günlük aktivite düzeyi veri olarak girilmiştir. Katılımcıların üzerindeki tüm metal aksesuarların ve takıların çıkarılıp, çıplak ve kuru ayak ile cihaz platformunun üzerine 
Korkmaz, B., Yoncalık, O. ve Güçlüöver, A. (2018). Gaziantep yöresi halk oyunları çalı̧̧malarının üniversite öğrencilerinin vücut kompozisyonu ve fiziksel uygunlukları üzerine etkisi. CBÜ Beden Ĕgitimi ve Spor Bilimleri Dergisi, 13(2), 388-404.

çıkıp tutma kollarını fazla sıkmadan, avuç içlerini kavrayacak şekilde tutup, ölçüm süresi bitene kadar (ortalama 55 saniye) anatomik duruşta, titremeden ve hareket etmeden, sabit durmas1 istenmiştir. Ölçüm yapılırken, deneğin üzerindeki giysilerin ağırlığı, yaklaşık dara ağırlığı olarak analizör ekranından düşülmüştür.

Antropometrik Ölçümler: Bu çalışmada katılımcıların, biceps bölgesinin çevresi, göğüs çevresi, üst bacak çevresi ve calf çevresi ölçümleri alınmıştır. Ölçümler, standart çift taraflı çok amaçlı ölçüm mezurası ile alınmıştır.

El Kavrama Kuvveti: "Jamar Hydraulic Hand" marka el dinamometresi ile kat1limc1lara ön test ve son test olmak üzere 12 haftalık süreçte iki kez ölçüm yapılmıştır. Her bir ölçümde katılımcılardan üçer tekrar yapması istenmiştir ve bu tekrarlardan en iyi sonuç kaydedilmiştir.

Sürat Koşusu: 20 metre arayla konulan koniler, bu mesafelerde ayarlanan fotosel ve başlangıç çizgileri katılımcılara anlatılmıştır. Örnek bir başlangıç ve bitişin nasıl olması gerektiği katılımcılara gösterilmiştir. Katılımcılardan tüm hızlarıyla koşmaları istenmiştir. Her katılımcı sırayla teste girmiştir. Katılımcılardan ikişer tekrar yapmaları istenmiş ve test bittikten sonra en iyi derece kayıtlara alınmıştır. Uygulanan tüm testler ve aşamaları hem ön testte hem de son testte aynı şekilde yapılmıştır.

Zig-Zag Koşusu: Çeviklik için Zig-Zag Testinin nasıl yapılmasını gerektiğini ayrıntılı olarak anlatmıştır (Mackenzie, 2005). Zig-Zag koşu testinde bir dikdörtgenin içinde ve dışında çapraz koşulması istenmiştir. Bu dikdörtgenin uzun kenarı 4.86 metre, kısa kenarı 3.04 metredir. Dikdörtgenin merkezine ve köşelerine de birer tane olmak üzere toplam 5 koni ile alan belirtilmiştir. Başlangıç ve bitiş çizgilerine yerleştirilen fotosel aracıllğıyla katılımcıların koşu süreleri tespit edilmiştir.

Esneklik: Otur uzan esneklik testi uygulanarak katılımciların oturma pozisyonunda ne kadar uzağa eriştiklerini bulmak amaçlanmıştır. Bu ölçüm için S\&R (Sit and Reach) sehpası kullanılmıştır. Katılımcılara testi nasıl uygulayacakları anlatılmış ve gösterilmiştir.

Dikey Stçrama ve Maksimum Bacak Gücü: Bu çalışmada Force Plate (Accu Power, OR 6-X-OP series) plakası kullanılmıştır. Yerde bulunun bir tabaka bilgisayara bağlanmış ve bilgisayara program kurulumu yapılmıştır. Kurulan programa ölçümlerden önce tüm katılımcıların bilgileri (cinsiyet, boy, kilo, spor dalı vb.) kaydedilmiştir. 
Korkmaz, B., Yoncalık, O. ve Güçlüöver, A. (2018). Gaziantep yöresi halk oyunları çalışmalarının üniversite öğrencilerinin vücut kompozisyonu ve fiziksel uygunlukları üzerine etkisi. CBÜ Beden Ĕgitimi ve Spor Bilimleri Dergisi, 13(2), 388-404.

\section{BULGULAR}

Bu bölümde deney ve kontrol grubunu katılımcılarının halk oyunları çalışmaları öncesi ve sonrası yapılan ölçümlere bağlı olarak biyomotorik testler ve çevre ölçümlerine ait sonuçlar verilmektedir.

Tablo 1. Deney grubu ön test ve son test karşılaş̧ırması

\begin{tabular}{|c|c|c|c|c|}
\hline & ort & SS & $\mathbf{t}$ & $\mathbf{p}$ \\
\hline Vücut Ağırlığı (Ön Test) & 63.973 & 10.5902 & \multirow{2}{*}{2.260} & \multirow{2}{*}{$.032 *$} \\
\hline Vücut Ağırlığı (Son Test) & 63.113 & 9.7418 & & \\
\hline Vücut Yağ Oranı (Ön test) & 19.053 & 8.4985 & \multirow{2}{*}{4.593} & \multirow{2}{*}{$.000^{*}$} \\
\hline Vücut Yağ Oranı (Son test) & 17.390 & 8.0731 & & \\
\hline Sağ El Kavrama Kuvveti (Ön test) & 46.200 & 14.3272 & \multirow{2}{*}{.000} & \multirow{2}{*}{1.000} \\
\hline Sağ El Kavrama Kuvveti (Son test) & 46.200 & 13.6997 & & \\
\hline Sol El Kavrama Kuvveti (Ön test) & 43.333 & 14.3703 & \multirow{2}{*}{-.051} & \multirow{2}{*}{.959} \\
\hline Sol El Kavrama Kuvveti (Son test) & 43.367 & 14.0356 & & \\
\hline 20 m Sürat (Ön test) & 3.2110 & .63295 & \multirow{2}{*}{4.342} & \multirow{2}{*}{$.000^{*}$} \\
\hline $20 \mathrm{~m}$ Sürat (Son test) & 3.1260 & .60337 & & \\
\hline Zig Zag (Ön test) & 16.8557 & 2.63622 & \multirow{2}{*}{4.043} & \multirow{2}{*}{$.000 *$} \\
\hline Zig Zag (Son test) & 16.2827 & 2.16402 & & \\
\hline Maksimum Bacak Gücü (Ön test) & 2704.03 & 1028.501 & \multirow{2}{*}{-2.779} & \multirow{2}{*}{$.009 *$} \\
\hline Maksimum Bacak Gücü (Son test) & 2827.97 & 1020.618 & & \\
\hline Dikey Sıçrama (Ön test) & 25.081 & 9.2570 & \multirow{2}{*}{-2.537} & \multirow{2}{*}{$.017 *$} \\
\hline Dikey Siçrama (Son test) & 26.867 & 8.6668 & & \\
\hline Calf Çevresi (Ön test) & 35.10 & 2.708 & \multirow{2}{*}{2.804} & \multirow{2}{*}{$.009 *$} \\
\hline Calf Çevresi (Son test) & 34.83 & 2.394 & & \\
\hline Biceps Çevresi (Ön test) & 29.13 & 3.329 & \multirow{2}{*}{2.408} & \multirow{2}{*}{$.023 *$} \\
\hline Biceps Çevresi (Son test) & 28.97 & 3.200 & & \\
\hline Göğüs Çevresi (Ön test) & 89.10 & 6.830 & \multirow{2}{*}{4.176} & \multirow{2}{*}{$.000^{*}$} \\
\hline Göğüs Çevresi (Son test) & 88.67 & 6.599 & & \\
\hline Üst Bacak Çevresi (Ön test) & 50.73 & 3.769 & \multirow{2}{*}{4.097} & \multirow{2}{*}{$.000 *$} \\
\hline Üst Bacak Çevresi (Son test) & 50.37 & 3.718 & & \\
\hline Esneklik (Ön test) & 30.93 & 4.877 & \multirow{2}{*}{-6.718} & \multirow{2}{*}{$.000^{*}$} \\
\hline Esneklik (Son test) & 32.40 & 4.931 & & \\
\hline
\end{tabular}

Deney Grubu katılımcılarının vücut ağırlığı, dikey sıçrama ve biceps çevre ölçümleri p $<0.05$ düzeyinde bulunmuştur. Vücut yağ oran1, 20m sürat koşusu, zig-zag koşu testi, maksimum bacak gücü, calf çevresi, üst bacak çevresi, gögüs çevresi ve esneklik ön test ve son test sonuçlarının karşıllaştırılması sonucu ise anlamlılık düzeyi $\mathrm{p}<0.01$ olarak tespit edilmiştir. Katılımcıların sağ el ve sol el kavrama kuvvetinde ise anlamlı bir sonuç elde edilmemiştir. 
Korkmaz, B., Yoncalık, O. ve Güçlüöver, A. (2018). Gaziantep yöresi halk oyunları çalı̧̧malarının üniversite öğrencilerinin vücut kompozisyonu ve fiziksel uygunlukları üzerine etkisi. CBÜ Beden Ĕgitimi ve Spor Bilimleri Dergisi, 13(2), 388-404.

Tablo 2. kontrol grubu ön test ve son test karşılaştırması

\begin{tabular}{|c|c|c|c|c|}
\hline & ort & ss & $\mathbf{t}$ & $\mathbf{p}$ \\
\hline Vücut Ağırlığı (Ön test) & 69.023 & 11.4633 & \multirow{2}{*}{-.510} & \multirow{2}{*}{.614} \\
\hline Vücut Ağırlığ (Son test) & 69.213 & 10.7042 & & \\
\hline Vücut Yağ Oranı (Ön test) & 21.127 & 9.0774 & \multirow{2}{*}{-.216} & \multirow{2}{*}{.831} \\
\hline Vücut Yağ Oranı (Son test) & 21.197 & 8.7502 & & \\
\hline Sağ El Kavrama Kuvveti (Ön test) & 44.233 & 13.8730 & \multirow{2}{*}{.402} & \multirow{2}{*}{.691} \\
\hline Sağ El Kavrama Kuvveti (Son test) & 43.933 & 14.0343 & & \\
\hline Sol El Kavrama Kuvveti (Ön test) & 41.400 & 14.5948 & \multirow{2}{*}{.103} & \multirow{2}{*}{.919} \\
\hline Sol El Kavrama Kuvveti (Son test) & 41.333 & 14.5657 & & \\
\hline 20 m Sürat (Ön test) & 3.4791 & .56532 & \multirow{2}{*}{-1.209} & \multirow{2}{*}{.236} \\
\hline 20 m Sürat (Son test) & 3.5437 & .57891 & & \\
\hline Zig Zag (Ön test) & 20.3017 & 3.76673 & \multirow{2}{*}{-1.848} & \multirow{2}{*}{.075} \\
\hline Zig Zag (Son test) & 20.7880 & 3.77269 & & \\
\hline Maksimum Bacak Gücü (Ön test) & 2732.47 & 1001.655 & \multirow{2}{*}{.481} & \multirow{2}{*}{.634} \\
\hline Maksimum Bacak Gücü (Son test) & 2714.33 & 986.409 & & \\
\hline Dikey Siçrama (Ön test) & 22.623 & 6.4063 & \multirow{2}{*}{.242} & \multirow{2}{*}{.811} \\
\hline Dikey Siçrama (Son test) & 22.503 & 7.0254 & & \\
\hline Calf Çevresi (Ön test) & 34.73 & 3.610 & \multirow{2}{*}{-2.262} & \multirow{2}{*}{$.031 *$} \\
\hline Calf Çevresi (Son test) & 34.93 & 3.542 & & \\
\hline Biceps Çevresi (Ön test) & 28.13 & 4.058 & \multirow{2}{*}{-1.928} & \multirow{2}{*}{.064} \\
\hline Biceps Çevresi (Son test) & 28.87 & 4.470 & & \\
\hline Göğüs Çevresi (Ön test) & 92.07 & 6.389 & \multirow{2}{*}{-1.439} & \multirow{2}{*}{.161} \\
\hline Göğüs Çevresi (Son test) & 92.13 & 6.285 & & \\
\hline Üst Bacak Çevresi (Ön test) & 54.53 & 4.754 & \multirow{2}{*}{-2.408} & \multirow{2}{*}{$.023 *$} \\
\hline Üst Bacak Çevresi (Son test) & 54.70 & 4.764 & & \\
\hline Esneklik (Ön test) & 27.60 & 4.987 & \multirow{2}{*}{1.725} & \multirow{2}{*}{.095} \\
\hline Esneklik (Son test) & 27.30 & 4.743 & & \\
\hline
\end{tabular}

${ }^{*} \mathrm{p}=0.05$ düzeyinde anlamlılık

Kontrol Grubu katılımcılarının üst bacak ve calf çevresi ön test ve son test sonucu halk oyunları çalışması yapmamasına rağmen $\mathrm{p}<0.05$ düzeyinde anlamlı bulunmuştur. Vücut ağırlığı, vücut yağ oran1, sağ el kavrama kuvveti, sol el kavrama kuvveti, 20 m sürat koşusu, zig-zag koşusu, maksimum bacak gücü, dikey sıçrama, biceps çevresi, göğüs çevresi ve esneklik ölçümlerinde anlamlı bir sonuç elde edilememiştir (Tablo2). 
Korkmaz, B., Yoncalık, O. ve Güçlüöver, A. (2018). Gaziantep yöresi halk oyunları çalışmalarının üniversite öğrencilerinin vücut kompozisyonu ve fiziksel uygunlukları üzerine etkisi. CBÜ Beden Ĕ̆itimi ve Spor Bilimleri Dergisi, 13(2), 388-404.

Tablo 3. Erkek katılımcıların ön test ve son test karşılaştırması

\begin{tabular}{|c|c|c|c|c|}
\hline & ort & ss & $\mathbf{t}$ & $\mathbf{p}$ \\
\hline Vücut Ağırlığı (Ön test) & 72.840 & 9.89 & \multirow{2}{*}{1.172} & \multirow{2}{*}{.251} \\
\hline Vücut Ağırlığ 1 (Son test) & 72.377 & 9.30 & & \\
\hline Toplam Vücut Yağ Oranı (Ön test) & 14.600 & 6.43 & \multirow{2}{*}{2.131} & \multirow{2}{*}{.042} \\
\hline Toplam Vücut Yağ Oranı (Son test) & 13.820 & 6.48 & & \\
\hline Sağ Kol Yağ Oranı (Ön test) & 12.403 & 6.90 & \multirow{2}{*}{1.869} & \multirow{2}{*}{.072} \\
\hline Sağ Kol Yağ Oranı (Son test) & 11.860 & 6.79 & & \\
\hline Sol Kol Yağ Oranı (Ön test) & 13.240 & 6.68 & \multirow{2}{*}{2.200} & \multirow{2}{*}{.036} \\
\hline Sol Kol Yağ Oranı (Son test) & 12.670 & 6.68 & & \\
\hline Sağ bacak Yağ Oranı (Ön test) & 16.730 & 7.00 & \multirow{2}{*}{3.101} & \multirow{2}{*}{.004} \\
\hline Sağ bacak Yağ Oranı (Son test) & 15.810 & 6.84 & & \\
\hline Sol bacak Yağ Oranı (Ön test) & 17.380 & 6.92 & \multirow{2}{*}{3.077} & \multirow{2}{*}{.005} \\
\hline Sol bacak Yağ Oranı (Son test) & 16.283 & 6.71 & & \\
\hline Karın Bölgesi Yağ Oranı (Ön test) & 15.623 & 7.45 & \multirow{2}{*}{3.017} & \multirow{2}{*}{.005} \\
\hline Karın Bölgesi Yağ Oranı (Son test) & 14.507 & 7.55 & & \\
\hline El Kavrama Kuvveti Sağ El (Ön test) & 55.400 & 11.86 & \multirow{2}{*}{.558} & \multirow{2}{*}{.581} \\
\hline El Kavrama Kuvveti Sağ El (Son test) & 54.933 & 11.93 & & \\
\hline El Kavrama Kuvveti Sol El (Ön test) & 53.000 & 11.80 & \multirow{2}{*}{-.129} & \multirow{2}{*}{.898} \\
\hline El Kavrama Kuvveti Sol El (Son test) & 53.100 & 10.99 & & \\
\hline Sürat Koşusu (Ön test) & 2.833 & 0.335 & \multirow{2}{*}{.460} & \multirow{2}{*}{.649} \\
\hline Sürat Koşusu (Son test) & 2.818 & 0.317 & & \\
\hline Zig Zag Çeviklik Koşusu (Ön test) & 16.880 & 3.19 & \multirow{2}{*}{-.719} & \multirow{2}{*}{.478} \\
\hline Zig Zag Çeviklik Koşusu (Son test) & 17.025 & 3.34 & & \\
\hline Maksimum Bacak Gücü (Ön test) & 3637.70 & 423.35 & \multirow{2}{*}{-.735} & \multirow{2}{*}{.468} \\
\hline Maksimum Bacak Gücü (Son test) & 3667.93 & 385.56 & & \\
\hline Dikey Siçrama (Ön test) & 30.668 & 4.86 & \multirow{2}{*}{-.574} & \multirow{2}{*}{.570} \\
\hline Dikey Siçrama (Son test) & 31.093 & 5.70 & & \\
\hline Calf Çevresi (Ön test) & 36.83 & 2.08 & \multirow{2}{*}{1.140} & \multirow{2}{*}{.264} \\
\hline Calf Çevresi (Son test) & 36.73 & 2.06 & & \\
\hline Biceps Çevresi (Ön test) & 30.87 & 2.99 & -1458 & 156 \\
\hline Biceps Çevresi (Son test) & 31.43 & 3.08 & -1.458 & .156 \\
\hline Göğüs Çevresi (Ön test) & 94.20 & 5.49 & 2.536 & 017 \\
\hline Göğüs Çevresi (Son test) & 93.97 & 5.44 & 2.536 & .011 \\
\hline Üst Bacak Çevresi (Ön test) & 52.93 & 4.12 & 1980 & 057 \\
\hline Üst Bacak Çevresi (Son test) & 52.97 & 4.19 & & \\
\hline Esneklik (Ön test) & 32.83 & 3.99 & 1580 & 123 \\
\hline Esneklik (Son test) & 33.23 & 4.47 & -1.588 & .123 \\
\hline
\end{tabular}

Ölçümü yapılan tüm parametrelerin erkek katılımcılara göre ön test ve son test karşılaştırılması yukarıdaki tabloda verilmiştir (Tablo 3). 
Korkmaz, B., Yoncalık, O. ve Güçlüöver, A. (2018). Gaziantep yöresi halk oyunları çalışmalarının üniversite öğrencilerinin vücut kompozisyonu ve fiziksel uygunlukları üzerine etkisi. CBÜ Beden Ĕ̆itimi ve Spor Bilimleri Dergisi, 13(2), 388-404.

Tablo 4. Kadın katılımcıların ön test ve son test karşılaştırması

\begin{tabular}{|c|c|c|c|c|}
\hline & ort & SS & $\mathbf{t}$ & $\mathbf{P}$ \\
\hline Vücut Ağırlığı (Ön test) & 60.15 & 8.69 & \multirow{2}{*}{.543} & \multirow{2}{*}{.591} \\
\hline Vücut Ağırlığı (Son test) & 59.95 & 8.16 & & \\
\hline Toplam Vücut Yağ Oranı (Ön test) & 25.58 & 7.28 & \multirow{2}{*}{2.072} & \multirow{2}{*}{.047} \\
\hline Toplam Vücut Yağ Oranı (Son test) & 24.76 & 6.72 & & \\
\hline Sağ Kol Yağ Oranı (Ön test) & 26.69 & 6.60 & \multirow{2}{*}{2.639} & \multirow{2}{*}{.013} \\
\hline Sağ Kol Yağ Oranı (Son test) & 25.88 & 6.11 & & \\
\hline Sol Kol Yağ Oranı (Ön test) & 26.83 & 6.71 & \multirow{2}{*}{2.633} & \multirow{2}{*}{.013} \\
\hline Sol Kol Yağ Oranı (Son test) & 25.97 & 6.23 & & \\
\hline Sağ bacak Yağ Oranı (Ön test) & 27.78 & 8.02 & \multirow{2}{*}{2.831} & \multirow{2}{*}{.008} \\
\hline Sağ bacak Yağ Oranı (Son test) & 26.66 & 7.40 & & \\
\hline Sol bacak Yağ Oranı (Ön test) & 27.93 & 7.99 & \multirow{2}{*}{3.030} & \multirow{2}{*}{.005} \\
\hline Sol bacak Yağ Oranı (Son test) & 26.64 & 7.46 & & \\
\hline Karın Bölgesi Yağ Oranı (Ön test) & 25.68 & 8.75 & \multirow{2}{*}{2.153} & \multirow{2}{*}{.040} \\
\hline Karın Bölgesi Yağ Oranı (Son test) & 24.82 & 7.95 & & \\
\hline El Kavrama Kuvveti Sağ El (Ön test) & 35.03 & 6.65 & \multirow{2}{*}{-.311} & \multirow{2}{*}{.758} \\
\hline El Kavrama Kuvveti Sağ El (Son test) & 35.20 & 6.59 & & \\
\hline El Kavrama Kuvveti Sol El (Ön test) & 31.73 & 6.93 & \multirow{2}{*}{.272} & \multirow{2}{*}{.788} \\
\hline El Kavrama Kuvveti Sol El (Son test) & 31.60 & 7.16 & & \\
\hline Sürat Koşusu (Ön test) & 3.85 & .321 & \multirow{2}{*}{.071} & \multirow{2}{*}{.944} \\
\hline Sürat Koşusu (Son test) & 3.85 & .364 & & \\
\hline Zig Zag Çeviklik Koşusu (Ön test) & 20.27 & 3.33 & \multirow{2}{*}{.907} & \multirow{2}{*}{.372} \\
\hline Zig Zag Çeviklik Koşusu (Son test) & 20.04 & 3.67 & & \\
\hline Maksimum Bacak Gücü (Ön test) & 1798.80 & 365.02 & \multirow{2}{*}{-1.677} & \multirow{2}{*}{.104} \\
\hline Maksimum Bacak Gücü (Son test) & 1874.37 & 456.92 & & \\
\hline Dikey Sıçrama (Ön test) & 17.03 & 3.18 & \multirow{2}{*}{-2.513} & \multirow{2}{*}{.018} \\
\hline Dikey Sıçrama (Son test) & 18.27 & 4.09 & & \\
\hline Calf Çevresi (Ön test) & 33.00 & 2.91 & \multirow{2}{*}{-.297} & \multirow{2}{*}{.769} \\
\hline Calf Çevresi (Son test) & 33.03 & 2.63 & & \\
\hline Biceps Çevresi (Ön test) & 26.40 & 2.96 & 000 & 1000 \\
\hline Biceps Çevresi (Son test) & 26.40 & 2.76 & .000 & \\
\hline Göğüs Çevresi (Ön test) & 86.97 & 5.89 & 1439 & 161 \\
\hline Göğüs Çevresi (Son test) & 86.83 & 5.76 & 1.439 & .101 \\
\hline Üst Bacak Çevresi (Ön test) & 52.33 & 5.20 & 328 & 745 \\
\hline Üst Bacak Çevresi (Son test) & 52.30 & 5.33 & .328 & .145 \\
\hline Esneklik (Ön test) & 25.70 & 3.48 & 2086 & 006 \\
\hline Esneklik (Son test) & 26.47 & 4.06 & & .000 \\
\hline
\end{tabular}

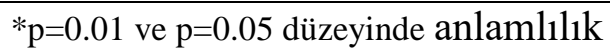

Ölçümü yapılan tüm parametrelerin kadın katılımcılara göre ön test ve son test karşılaştırılması yukarıdaki tabloda verilmiştir (Tablo 4). 
Korkmaz, B., Yoncalık, O. ve Güçlüöver, A. (2018). Gaziantep yöresi halk oyunları çalı̧̧malarının üniversite öğrencilerinin vücut kompozisyonu ve fiziksel uygunlukları üzerine etkisi. CBÜ Beden Ĕgitimi ve Spor Bilimleri Dergisi, 13(2), 388-404.

Tablo 5. Deney grubu ve kontrol grubu ön test son test karşılaş̧ırılması

\begin{tabular}{lccc}
\hline & $\mathrm{f}$ & $\mathrm{p}$ & $\mathrm{p}$ kare \\
\hline Vücut Ağırlığı & 1.683 & .000 & .967 \\
\hline Vücut Yağ Oranı & 1.197 & .000 & .955 \\
\hline Sağ El Kavrama Kuvveti & .169 & .683 & .003 \\
\hline Sol El Kavrama Kuvveti & .040 & .843 & 0.01 \\
\hline 20 Metre Sürat Koşusu & 375.582 & .000 & .868 \\
\hline Zig Zag Koşusu & 392.912 & .000 & .873 \\
\hline Maksimum Bacak Gücü & 1.096 & .000 & .951 \\
\hline Dikey Sıçrama & 279.764 & .000 & .831 \\
\hline Calf Çevresi & 2.405 & .000 & .977 \\
\hline Biceps Çevresi & 4.885 & .031 & 0.79 \\
\hline Göğüs & 1.469 & .000 & .996 \\
\hline Üst Bacak Çevresi & 5.409 & .000 & .990 \\
\hline Esneklik & 1.131 & .000 & .952 \\
\hline \multicolumn{1}{c}{$* \mathrm{p}=0.01$ ve $\mathrm{p}=0.05$ düzeyinde anlamlı11k } & & &
\end{tabular}

Deney ve Kontrol Gruplarının ön test ve son test karşılaştırmalarında vücut ağırlığı, vücut yağ oran1, 20 m sürat koşusu, zig-zag koşusu, maksimum bacak gücü, dikey sıçrama, calf çevresi, üst bacak çevresi, göğüs çevresi ve esneklik ölçümleri sonucunda $\mathrm{p}<0.01$ düzeyinde deney grubu lehine anlamlı sonuç tespit edilmiştir. Biceps çevresi ölçümleri karşılaştırıldığında anlamlıl1k düzeyi deney grubu lehine $p<0.05$ olarak bulunmuştur. Sağ el ve sol el Kavrama ölçümleri sonucunda deney grubu ile kontrol grubu arasında anlamlı bir fark olmadığı tespit edilmiştir (Tablo5).

\section{TARTIŞMA VE SONUÇ}

Bu çalışmada Kırıkkale Üniversitesinde öğrenim gören 30 deney grubu (15 erkek, 15 kadın), 30 kontrol grubu (15 erkek, 15 kadın) olmak üzere 60 öğrencinin, halk oyunları çalışmaları öncesi ve sonrası bazı fiziksel, fizyolojik özellikleri ve esneklik, sürat, kuvvet, çeviklik gibi performansları karşılaştırılmıştır. Araştırmaya katılan öğrencilerin, yaş, kilo, boy gibi özelliklerinin yanı sıra vücut kompozisyonu, 20 metre sürat koşu zamanı, zig zag çeviklik koşu zamanı, esneklik testi, el kavrama kuvveti testi, maksimum bacak gücü testi ve bazı çevre ölçümleri alınmıştır. Bu bölümde katılımcıların test ve ölçüm verilerinin analiz edilmesinden sonra, literatürdeki benzer çalışmalarla karşılaştırılması yapılmış ve yorumlanmıştır. 
Korkmaz, B., Yoncalık, O. ve Güçlüöver, A. (2018). Gaziantep yöresi halk oyunları çalı̧̧malarının üniversite öğrencilerinin vücut kompozisyonu ve fiziksel uygunlukları üzerine etkisi. CBÜ Beden Ĕgitimi ve Spor Bilimleri Dergisi, 13(2), 388-404.

Araştırmaya katılan deney grubu öğrencilerinin yaş ortalaması 20.43 \pm 1.1 yıl, kontrol grubu öğrencilerinin yaş ortalaması $20.87 \pm 1.0$ yıl, deney grubu öğrencilerinin boy ortalaması $171.67 \pm 9.5 \mathrm{~cm}$, kontrol grubu öğrencilerinin boy ortalamas1 $172.07 \pm 8.6 \mathrm{~cm}$, deney grubu öğrencilerinin ortalama ağırlığı $63.973 \pm 10.5 \mathrm{~kg}$, kontrol grubu öğrencilerinin ortalama ağırlı̆̆ $69.023 \pm 11.4 \mathrm{~kg}$ olarak saptanmıştır.

Ünveren (2006) tarafından yapılan üniversite öğrencilerine yönelik halk oyunları egzersizlerinin fiziksel ve fizyolojik etkisinin araştırıldığı çalışmada deney grubunun yaş ortalaması 20.61 \pm 1.42 yıl, kontrol grubunun yaş ortalaması $21.33 \pm 1.50$ yıl olarak saptanmıştır. Kay (2008) tarafından yapılan benzer araştırmada ise katılımcıların vücut ağırlığı ortalamaları $66.40 \pm 11.12 \mathrm{~kg}$ olarak tespit edilmiştir. Alp (2010) tarafından yapılan halk oyunlarının vücut kompozisyonu üzerine etkisinin araştırıldığı çalışmada erkeklerin boy ortalaması $172.08 \pm 5.80$ $\mathrm{cm}$, kadınların boy ortalaması $159.75 \pm 5.04 \mathrm{~cm}$ bulunmuştur. Bu çalışmalardaki katılımcıların yaş, vücut ağırlığı ve boy uzunluğu gibi bazı demografik özellikleri bu araştırmayla benzerlik göstermektedir.

Bu çalışmada ölçümü yapılan vücut yağ oranı değerlerinden, tüm vücut yă̆ oranının deney grubundaki ön test sonuçları $19.053 \pm 8.4985 \mathrm{~kg}$ olup son testte anlamlı $(\mathrm{p}<0.01)$ bir düşüş olarak $17.390 \pm 8.0731 \mathrm{~kg}$ değerlerine gelmiştir. Kontrol grubunda ise beklendik şekilde tüm vücut yağ oranında anlamlı bir değişiklik meydana gelmemiştir. Kay’ın (2008) halk oyunlarının üniversite öğrencilerinin bazı fiziksel ve fizyolojik parametrelerine olan etkisini incelediği çalışmasında halk oyunları oynayan horon grubun ön testteki tüm vücut yăg oranı $13.643 \pm 2.775$ $\mathrm{kg}$, son testte ise $13.120 \pm 2.626 \mathrm{~kg}$ bulunmuştur ve ölçümler arasındaki istatistiki fark $\mathrm{p}<0.05$ anlamlılık düzeyindedir. Yine aynı çalışmada, zeybek grubu öğrencilerinin tüm vücut yağ oranları ön test sonucu $22.503 \pm 6.755 \mathrm{~kg}$ iken son testte bu ortalama $22.263 \pm 6.715 \mathrm{~kg}$ olarak tespit edilmiştir. Kay’ın çalışmasının vücut yağ oranı değerlerinde değişim üzerinden analiz edildiğinde bu çalışma ile benzerlik göstermektedir. Alp’ın (2010) halk oyunlarının ritim duygusu ve vücut kompozisyonu üzerine etkisini incelediği araştırmasında katılımcıların vücut yağ oranı değerlerini Yuhasz formülüne göre hesaplamış olup, erkek katılımcılarda ön testte $7.460 \pm 1.393 \mathrm{~kg}$ son testte $7.372 \pm 1.572 \mathrm{~kg}$ ortalamalarını tespit etmiş ancak anlamlı bir farklılık bulunamamıştır $(\mathrm{p}=0.328)$. Kadın katılımcılarda ise ön testte $10.738 \pm 3.286 \mathrm{~kg}$ son testte de $10.56 \pm 0.978 \mathrm{~kg}$ hesaplanmış ve aynı şekilde anlamlı farklılık bulunamamıştır. Bu araştırma 
Korkmaz, B., Yoncalık, O. ve Güçlüöver, A. (2018). Gaziantep yöresi halk oyunları çalı̧̧malarının üniversite öğrencilerinin vücut kompozisyonu ve fiziksel uygunlukları üzerine etkisi. CBÜ Beden Ĕgitimi ve Spor Bilimleri Dergisi, 13(2), 388-404.

sonuçları Alp'in (2010) sonuçları ile karşılaştırıldığında, iki araştırma arasında bir fark görülmüşs olup bunun sebebinin de ölçüm yöntemleri, katılımcıların yaşları ve oynadıkları halk oyunları yöresi olabileceği öngörülmektedir.

Aydos ve Kürkçü (1997), spor yapan ve spor yapmayan ortaöğrenim öğrencilerinin fiziksel ve fizyolojik özelliklerini karşılaştırdıkları araştırmada katılımcıların sağ el kavrama kuvveti sonuçlarını $32.45 \pm 8.55 \mathrm{~kg}$ elde etmişlerdir ve bu sonuçlar kontrol grubunun sonuçları $22.83 \pm 5 \mathrm{~kg}$ ile karşılaştırıldığında anlamlı düzeyde farklılık bulunmuştur. Spor yapan ve yapmayan bireyler arasında el kavrama kuvveti değerlerinde anlamlı fark olduğu tespit edilmiştir. Bu çalışmada el kavrama kuvveti ölçüm sonuçları incelendiğinde deney grubu sağ el kavrama kuvveti ön test ortalaması $46.200 \pm 14.32 \mathrm{~kg}$ elde edilmiş iken son testte bir değişim olmayarak yine $46.200 \pm 13.69 \mathrm{~kg}$ ortalaması bulunmuştur ve anlamlı bir farkl1lık tespit edilmemiştir. Sol el kavrama kuvveti ön test sonuçları $43.33 \pm 14.37 \mathrm{~kg}$ iken son testte $43.367 \pm 14.03 \mathrm{~kg}$ değerinde kalmıştır ve yine anlamlı bir sonuç elde edilmemiş̧ir. Literatürdeki benzer çalışmalar incelendiğinde yapılan spor dalına göre el kavrama kuvvetinde olumlu yönde değişim gözlenmiş olup halk oyunları branşının el kavrama kuvveti değerlerine herhangi bir etkisi olmadığı görülmüştür.

Ölçümler sonucu, deney grubunun 20 metre sürat koşusu ön test ve son test değerlerine bakıldığında \%2.64 oranında gelişim görülmüştür. Ön testte $3.21 \pm 0.63$ saniye olan ortalama son testte $3.12 \pm 0.60$ saniye olarak ölçülmüsstür. Kontrol grubunun ön testte $3.47 \pm 0.56$ saniye olan verileri son testte $\% 1.85$ gerileyerek ortalaması $3.54 \pm 0.57$ saniye olarak saptanmıştır. $\mathrm{Bu}$ sonuçlardan elde edilen verilerin analiz edilmesi sonucunda halk oyunları oynayan bireylerin süratlerinde olumlu yönde gelişmeler olduğu görülmektedir. Türk Halk Oyunları öğretim yöntemlerinin çabukluk, sürat ve esneklik üzerindeki etkisinin incelendiği çalışmada Ağca, (2017) katılımcılara zig zag çeviklik koşu testini uygulamış ve yapılan ölçüm sonucu $17.19 \pm 3.69$ saniye değerini tespit etmiştir. Farklı bir öğretim yöntemi ile yaptığı halk oyunları çalışması yaptığı grup sonucu ise yine benzer sonuçlar bulmuş ve $17.89 \pm 3.88$ saniye değerlerini tespit etmiştir.

$\mathrm{Bu}$ çalışmada zig zag çeviklik koşu testinin deney grubundaki ortalamaları ön test ve son testte sırayla şu şekilde bulunmuştur, $16.855 \pm 2.63$ saniye ve $16.282 \pm 2.16$ saniyedir. Deney grubu zig zag çeviklik koşu değerleri arasında $\mathrm{p}<0.01$ düzeyinde anlamlılık tespit edilmiştir. 
Korkmaz, B., Yoncalık, O. ve Güçlüöver, A. (2018). Gaziantep yöresi halk oyunları çalı̧̧malarının üniversite öğrencilerinin vücut kompozisyonu ve fiziksel uygunlukları üzerine etkisi. CBÜ Beden Ĕgitimi ve Spor Bilimleri Dergisi, 13(2), 388-404.

Kontrol grubu zig zag çeviklik koşusu ön testte 20.301士3.76 saniye ortalaması elde edilmiştir. Son testte ise anlamlı bir farklılık olmadığı görülmüş ve $20.788 \pm 3.77$ saniye ortalaması tespit edilmiştir. Halk oyunları egzersizlerine katılan öğrencilerin az da olsa çeviklik özelliklerinde \%3.39 gelişim tespit edilmiştir. Gruplar birbirleri ile karşılaştırıldığında deney grubunun verileri kontrol grubunun verilerine göre $\mathrm{p}<0.01$ anlamlılık düzeyinde anlamlı olduğu görülmüştür.

Dikey sıçrama testlerinin sonuçları incelendiğinde, deney grubu öğrencilerinin ön testte $25.081 \pm 9.25 \mathrm{~cm}$ olan değerleri son testte artış göstererek $26.867 \pm 8.66 \mathrm{~cm}$ değerine gelmiştir. $\mathrm{Bu}$ artışa istatistiksel olarak bakıldığında ortalama değerlerinde \%7.12 oranında gelişim gösterdiği tespit edilmiştir. Anlamlılık düzeyi ise $\mathrm{p}<0.05$ olarak bulunmuştur. Kontrol grubu öğrencilerinin ön testte $22.623 \pm 6.40 \mathrm{~cm}$ olan ortalamaları son testte $22.503 \pm 7.02 \mathrm{~cm}$ olarak değişim göstermemiştir( $(\mathrm{p}>0.05)$. Gruplar arası karşılaştırma yapıldığında deney grubunun kontrol grubuna göre gelişimi $\mathrm{p}<0.05$ düzeyinde anlamlı olarak tespit edilmiştir.

Dikey sıçrama testlerinin bulunduğu literatürler incelendiğinde, ölçüm yöntemlerindeki değişiklikler ve kullanılan aletler ortaya çıkan sonuçlar arasında büyük farklılıklar göstermektedir. Dikey sıçrama ölçüm yöntemleri yapılan araştırmalar arasındaki bu farklılıkların sebebini göstermektedir. Serin (2015) yaptığı çalışmada, dikey sıçrama testlerini smart speed lite sistemi ile ölçmüş ve katılımcılarda $45.94 \pm 6.18 \mathrm{~cm}$ değerini elde etmiştir. Macit (2014) sporcularda dikey sıçrama yüksekliklerini araştırdığı çalışmasında, dikey sıçrama ölçümü için new test jump mat cihazını kullanmıştır ve ölçüm yapılırken sporcuların daha yükseğe sıçraması için sporcuların dizlerini kırmasına ve ellerini serbest olarak hareket ettirmesine izin vermiştir. $\mathrm{Bu}$ şekilde yapılan ölçümlerde 34 deneğin ortalaması $43.71 \pm 7.00 \mathrm{~cm}$ olarak tespit edilmiştir. Yıldız'ın (2001) futbolcular üzerine yaptığı araştırmada, 8 haftalık antrenman programı uygulamıştır. Ön test ve son test olarak iki test gerçekleştirmiştir. Bu araştırmada ön testte $41.25 \pm 1.86 \mathrm{~cm}$ olan veriler son testte $49.91 \pm 1.92 \mathrm{~cm}$ ortalamasına çıkmış ve anlamlı bir farklılık tespit etmiştir. Genel olarak literatüre bakıldığında katılımcılara uygulanan egzersiz programından sonra dikey sıçrama testlerinde anlamlı farklılıklar olduğu görülmüştür.

Vücut kompozisyonu ve çeviklik arasındaki ilişkinin incelendiği çalışmada, katılımcıların vücut çevre uzunlukları ölçümleri araştırılmıştır. 18 katılımcı üzerinde yaptığı ölçümlerde baldır çevresini $37.69 \pm 1.526 \mathrm{~cm}$, uyluk çevresini $55.81 \pm 2.408 \mathrm{~cm}$, ön kol çevresini $30.28 \pm 1.817 \mathrm{~cm}$ ve

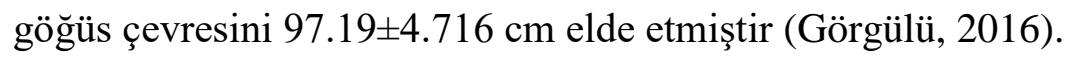


Korkmaz, B., Yoncalık, O. ve Güçlüöver, A. (2018). Gaziantep yöresi halk oyunları çalı̧̧malarının üniversite öğrencilerinin vücut kompozisyonu ve fiziksel uygunlukları üzerine etkisi. CBÜ Beden Ĕgitimi ve Spor Bilimleri Dergisi, 13(2), 388-404.

Literatürdeki çalışmalarla benzerlik gösteren bu araştırmada deney grubunun baldır çevresi $35.10 \pm 2.708 \mathrm{~cm}$ iken son testte $34.83 \pm 2.394 \mathrm{~cm}$ değerine gelmiştir. Bu değişimin istatistiksel olarak oranı \%0.76 olmasına rağmen $\mathrm{p}<0.05$ düzeyinde anlamlı olarak tespit edilmiştir. Kontrol grubu baldır ön test sonuçları $34.73 \pm 3.610 \mathrm{~cm}$ iken $34.93 \pm 3.542 \mathrm{~cm}$ değerine gerilemiştir ve anlamlı bir farklılık bulunmamıştır. Deney grubu öğrencilerinin ön kol çevresi uzunluğu ön testte $29.13 \pm 3.329 \mathrm{~cm}$, son testte ise $28.97 \pm 3.200 \mathrm{~cm}$ tespit edilmiştir. Kontrol grubunun ön kol çevresi uzunlukları ise $28.13 \pm 4.058 \mathrm{~cm}$ iken son testte $28.87 \pm 4.470 \mathrm{~cm}$ olarak kaydedilmiştir. Ön kol değerleri incelendiğinde deney grubunda anlamlı bir farklılık tespit edilmiş olup kontrol grubundaki değişim anlamlı olarak tespit edilmemiştir. Göğüs çevresi ölçümlerinde deney grubunun ön test ortalamas1 $89.10 \pm 6.830 \mathrm{~cm}$, son test ortalamas1 $88.67 \pm 6.599 \mathrm{~cm}$ olarak ölçülmüsstür ve anlamlı farklılık tespit edilmiştir. Kontrol grubu verileri incelendiğinde anlamlı bir farklılık olmadığı görülmüştür. Üst bacak ölçümleri sonucunda deney grubunda sıkılaşma tespit edilirken, kontrol grubunda genişleme söz konusu olmuştur. Deney grubu ön test sonuçları $50.73 \pm 3.769 \mathrm{~cm}$ değerinden $50.37 \pm 3.718 \mathrm{~cm}$ değerine inmiştir. Kontrol grubu ön testi $54.53 \pm 4.754 \mathrm{~cm}$ iken son testte $54.70 \pm 4.764 \mathrm{~cm}$ olarak bulunmuştur. Genel olarak çevre uzunluklarının sonuçlarına bakıldığında deney grubunda sıkılaşma meydana gelmiştir ve uzunluklar azalma göstermiştir. Kontrol grubunda ise herhangi bir değişim olmamış ya da çevre uzunluklarında genişleme meydana gelmiştir.

Ertem (2015) tarafindan badmintoncularda antropometrik ve fiziksel özelliklerin esneklik üzerine etkisinin incelendiği çalışmada erkek katılımcıların esneklik ölçümlerini $17.8 \pm 12.6 \mathrm{~cm}$ olarak tespit edilmiştir. Karakaş'ın (2017) fiziksel çalışmaların esneklik üzerine etkisini incelediği çalışmada, kontrol grubunun esneklik değerini $33.50 \pm 7.07 \mathrm{~cm}$, deney grubunun ise $34.60 \pm 8.58 \mathrm{~cm}$ olarak tespit etmiştir. Bu çalışmada ölçümü yapılan esneklik testinde deney grubunda anlamlı bir farklılık elde edilmiştir $(\mathrm{p}<0.01)$. Deney grubunun ön test verileri $30.93 \pm 4.877 \mathrm{~cm}$, son test verileri ise $32.40 \pm 4.931 \mathrm{~cm}$ olarak bulunmuştur. Halk oyunları antrenmanları sonrası deney grubu öğrencilerinin esneklik değeri \%4.75 oranında artmıştır. Kontrol grubu verileri incelendiğinde ön testte $27.60 \pm 4.987 \mathrm{~cm}$ olan ortalamaları son testte $27.30 \pm 4.743 \mathrm{~cm}$ olmuştur ve anlamlı bir farklılık olmamıştır.

$\mathrm{Bu}$ çalışmadan elde edilen bulgular; halk oyunları branşının, üniversite öğrencilerinin antropometrik özellikleri, vücut kompozisyonu ve bazı motorik becerileri üzerinde etkili 
Korkmaz, B., Yoncalık, O. ve Güçlüöver, A. (2018). Gaziantep yöresi halk oyunları çalışmalarının üniversite öğrencilerinin vücut kompozisyonu ve fiziksel uygunlukları üzerine etkisi. CBÜ Beden Ĕgitimi ve Spor Bilimleri Dergisi, 13(2), 388-404.

olduğunu göstermektedir. Halk oyunları üzerine yapılan bu araştırma; diğer spor dalları tarafından önemli görülen, seçilmiş motor özellikler ve fiziksel uygunluk bileşenlerinin ortaya konması açısından, hem araştırmanın etkisini hem de diğer spor dalları ile karşılaştırılması yönüyle önemini ortaya koymuştur. Sonuç olarak, 12 hafta süreyle, haftada 3 gün ve günde 90 dakika süreyle yapılan halk oyunları egzersizlerinin üniversite öğrencilerinde, vücut ağırlığı kaybı, vücut yağ oranında azalma, sürat ve çeviklik düzeyinde artış, maksimum bacak gücü, dikey sıçrama ve esneklik değerlerinde artış, bazı çevre uzunluklarında yağ ve kilo kaybından dolayı sıkılaşma gösterdiği tespit edilmiştir. El kavrama kuvveti ve bazı çevre ölçümlerinde anlamlı farklılık tespit edilmemiştir. Halk oyunlarının el kavrama kuvvetine etkisinin olmadığını söylenebilir. Halk oyunları antrenman programına dâhil olan öğrencilerin, halk oyunları oynamayan ve herhangi yüksek tempoda aktivite yapmayan öğrencilere göre kuvvet, sürat, çeviklik ve esneklik gibi bazı fiziksel uygunluk bileşenlerinde daha iyi sonuçlar almalarının yanı sıra vücut ağırlıklarında ve vücut yağ oranlarında daha iyi oranlara sahip oldukları tespit edilmiştir. Bu bileşenlerdeki farklılığın oluşmasında yapılan antrenmanların temposu, sıklığı ve kalitesinin etkili olduğu düşünülmektedir.

$\mathrm{Bu}$ çalışmada elde edilen sonuçlara paralel olarak, halk oyunları egzersizlerinin insan sağlı̆̆ üzerindeki olumlu etkileri incelenip, tüm toplumda halk oyunlarının öneminin artırılıp, yaygınlaştırılması amaçlanabilir. Katılımcılara beslenme ve diyet programı uygulanmamıştır. Beslenme ve diyet programları uygulanarak halk oyunları çalışmaları yapılıp, beslenmenin etkileri incelenebilir. Vücut yağ oranı önemli olan branşlarda, bu çalışma yardımcı antrenman olarak uygulanabilir. Bacak kuvvetinin önemli olduğu çalışmalarda (halter, güreş vb.) antrenman monotonluğunu gidermek ve sporcuları psikolojik anlamda zinde tutmak için ara (yardımcı) antrenman olarak uygulanabilir. Bu program antrenmanların daha eğlenceli ve neşeli hale gelmesini sağlayabilir. 
Korkmaz, B., Yoncalık, O. ve Güçlüöver, A. (2018). Gaziantep yöresi halk oyunları çalışmalarının üniversite öğrencilerinin vücut kompozisyonu ve fiziksel uygunlukları üzerine etkisi. CBÜ Beden Ĕ̆itimi ve Spor Bilimleri Dergisi, 13(2), 388-404.

\section{KAYNAKLAR}

Ağca, S. (2017). Türk halk oyunları öğretim yöntemlerinin çabukluk, esneklik ve sürat üzerine etkisi. Yayımlanmamış Yüksek Lisans Tezi. İnönü Üniversitesi/Sağlık Bilimleri Enstitüsü, Malatya.

Alp, M. A. (2010). Halk oyunlarının ritim duygusu, vücut kompozisyonu ve reaksiyon zamanın gelişimi üzerine etkisi. Yayımlanmamış Yüksek Lisans Tezi. Sakarya Üniversitesi/ Sosyal Bilimler Enstitüsü, Sakarya.

Aydos, L., \& Kürkçü, R. (1997). 13-18 yaş grubu spor yapan ve yapmayan orta öğrenim gençliğinin fiziksel ve fizyolojik özelliklerinin karşıllaştırılması. Gazi Beden Ĕ̈itimi ve Spor Bilimleri Dergisi, 2(2), 31-38.

Blimkie, C.J. (1992). Resistance training during prand early puberty: efficacy, trainability, mechanisms, and persistance. Can $J$ Sport Sci, 7(14), 264-279.

Bompa, T. (2014). Dönemleme antrenman kuramı ve yöntemi. (5. Baskı). Ankara: Spor Yayınevi.

Ceyran, O. (2001). Türk halk dansları.(s.16-17). İzmir: Şensoy Matbaası.

Ertem, A. (2014). Üniversitelerarası müsabakalarda süper lig kategorisinde oynayan badmintoncularda antropometrik ve fiziksel özelliklerin çeviklik ve esneklik yeteneği ile ilişkisi. Yayımlanmamış Yüksek Lisans Tezi. Cumhuriyet Üniversitesi/Sağlık Bilimleri Enstitüsü, Sivas.

Görgülü, T. (2016). Vücut kompozisyonu ile çeviklik arasındaki ilişki. Yayımlanmamış Yüksek Lisans Tezi. Selçuk Üniversitesi/Sağlık Bilimleri Enstitüsü, Konya.

Kaeppler, A. (2003). Halk biliminde kuram ve yaklaşımlarda dans. Milli Folklor Dergisi, 5(2), 382-385.

Karakaş, C. ( 2017). Elit güreşçilerde hazırlık dönemi antrenman programları içerisinde fiziksel çalışmaların esneklik üzerine etkileri. Yayımlanmamış Doktora Lisans Tezi. İstanbul Gelişim Üniversitesi/Sağlık Bilimleri Enstitüsü, İstanbul.

Kay, H. C. (2008). 12 haftalık düzenli halk oyunları çalışmalarının, üniversiteli öğrencilerin bazı fiziksel ve fizyolojik parametrelerine etkisinin incelenmesi (Afyonkarahisar örneği). Yayımlanmamış Yüksek Lisans Tezi. Afyon Kocatepe Üniversitesi/ Sağlik Bilimleri Enstitüsü, Afyonkarahisar.

Macit, Ö. (2014). Sporcularda dikey sıçrama yükseklikleri ve squat çalışmalarında elektromiyogram kayıtlarının incelenmesi. Yayımlanmamış Yüksek Lisans Tezi. Erciyes Üniversitesi/Sağlık Bilimleri Enstitüsü, Kayseri.

Mackenzıe, B. (2005). Zig-zag testi. https://www.brianmac.co.uk/zigzag.htm [Accessed 19/11/2018].

Önal, L., Gerek Z., Bedir, F. ve Bedir, D. (2017). Halk dansları ile ilgilenen üniversite öğrencilerinin davranış özellikleri ile eğlence eğilimleri arasındaki ilişkinin incelenmesi. Atatürk Üniversitesi Beden Ĕgitimi ve Spor Bilimleri Dergisi, 19(3), 104-114.

Özer, K. (2001). Fiziksel uygunluk. Ankara: Nobel Yayın Dağıtım.

Serin, E. (2015). Anaerobik dayanıklılık ile dikey sıçrama arasındaki ilişki. Yayımlanmamış Doktora Lisans Tezi. Selçuk Üniversitesi/Sağlık Bilimleri Enstitüsü, Konya.

Sünger, I. (2015). Şanlıurfa oyunları ve yöresel giysileri. Ankara: Şahin Ofset.

Şensoy, E. (1991). Çorum halk oyunları ve giysileri. Ankara: Cihan Kitabevi.

Ünveren, A. (2006). Düzenli halk oyunları çalışmalarının bazı fiziksel ve fizyolojik parametrelere etkisi. Atatürk Üniversitesi Beden Eğitimi ve Spor Bilimleri Dergisi, 8(1), 28-35.

Üzümcü, Ş. (2016). Urfa halk oyunları (2. Baskı). Şanlıurfa: Eyyübiye Belediyesi Kültür Yayınları.

Yıldız, S. (2001). 8 haftalık pliometrik antrenman programının futbolcuların dikey siçramaları ile bazı fiziksel ve fizyolojik parametreleri üzerine etkisi. Yayımlanmamış Yüksek Lisans Tezi. Muğla Üniversitesi/Sosyal Bilimler Enstitüsü, Muğla.

Zorba, E. (2001). Fiziksel uygunluk (2. Bask1). Muğla: Gazi Kitabevi. 